\title{
Un site de référence de très hautes terrasses fluviales dans la zone de confluence Ourthe-Meuse à Bois de Breux (Liège) ${ }^{1}$
}

Étienne JUVIGNÉ et Jean VAN CAMPENHOUT

Université de Liège, Département de Géographie, Bât. B1 1 - Quartier Village 4, Clos Mercator, 3 ; B-4000 Liège. contact : ejuvigne@skynet.be

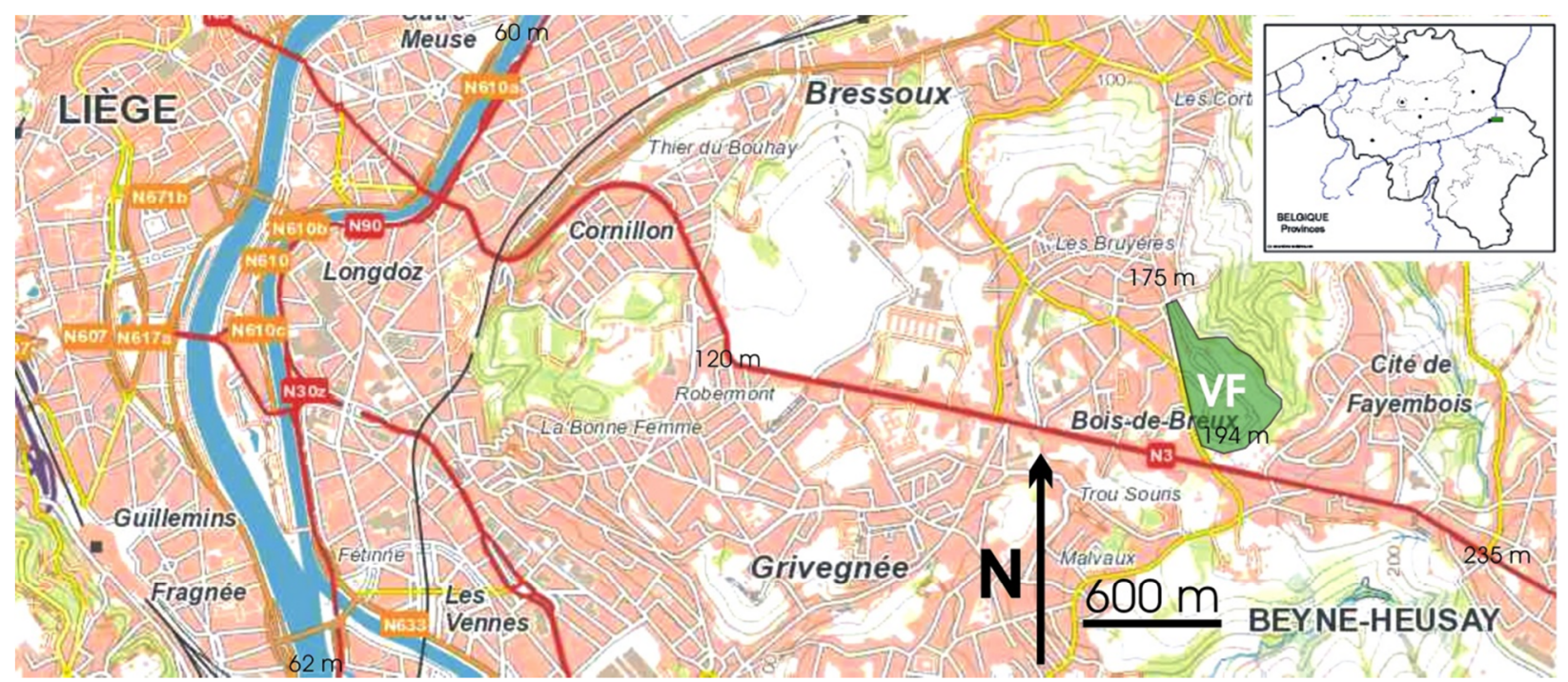

Figure 1 : Localisation du site étudié : le lotissement du Verger de Fayenbois (VF) à Bois de Breux. 